\title{
Activation of the Neutrophil Bactericidal Activity for Nontypable Haemophilus influenzae by Tumor Necrosis Factor and Lymphotoxin
}

\author{
ANNE-MARIE TAN, ANTONIO FERRANTE, DAVID H. B. GOH, DON M. ROBERTON, AND \\ ALLAN W. CRIPPS \\ Department of Immunology, Women's and Children's Hospital South Australia, 5006 [A.-M.T., A.F., \\ D.M.R.]; Department of Paediatrics, University of Adelaide, South Australia, 5006 [D.M.R.]; Faculty of \\ Medicine, University of Newcastle, New South Wales, 2300 Australia [A.W.C.]
}

\begin{abstract}
Previous studies have suggested that, in vivo, activated $\mathrm{T}$ lymphocytes and neutrophils are important in immunity to nontypable Haemophilus influenzae. We now extend this work by showing that neutrophils pretreated with products of activated $\mathrm{T}$ lymphocytes or activated macrophages show significantly enhanced killing of nontypable $H$. influenzae. Lymphotoxin, a product of activated $\mathrm{T}$ lymphocytes, significantly enhanced the neutrophil-mediated killing of nontypable $H$. influenzae, and tumor necrosis factor, produced by activated $\mathrm{T}$ lymphocytes as well as macrophages stimulated by activated $\mathrm{T}$ lymphocytes, also significantly increased the bactericidal activity of neutrophils. These cytokine-induced effects were seen with short pretreatment times of neutrophils and were maximal by $30 \mathrm{~min}$. The killing of $H$. influenzae by neutrophils required the presence of heat-labile opsonins. In the absence of these opsonins, both tumor necrosis
\end{abstract}

\section{ABSTRACT}

factor and lymphotoxin were unable to promote the killing of the bacteria by neutrophils. Furthermore, the results showed that tumor necrosis factor-primed neutrophils displayed significantly increased expression of CR3 and CR4 that was associated with increased phagocytosis of complement-opsonized nontypable $H$. influenzae. These cytokines may play an important role in immunity toward nontypable $H$. influenzae by stimulating neutrophil bactericidal activity. (Pediatr Res 37: 155-159, 1995)

TNF, tumor necrosis factor

Abbreviations

LT, lymphotoxin

CR3, complement receptor type 3 (CD18/CD11b)

CR4, complement receptor type 4 (CD18/CD11c)

HBSS, Hanks' balanced salt solution
Nontypable Haemophilus influenzae is a common respiratory pathogen. It is carried in the nasopharynx of $70-80 \%$ of healthy children (1). Colonization rates increase during respiratory illness (2). In particular, colonization of the nasopharynx with nontypable $H$. influenzae may exceed $95 \%$ at the time of otitis media (3), when the organism may compose $50 \%$ of the total bacterial flora (4). Although invasive disease, such as bacteremia, is uncommon with nontypable $H$. influenzae, local infection is frequent. Nontypable $H$. influenzae is the second leading cause of acute otitis media and sinusitis and the leading cause of recurrent or chronic otitis media in children (5-8).

The protective role of antibody against nontypable $H$. influenzae respiratory infections in both humans and rat models is now questionable. High levels of antibody to this organism are present in serum, saliva, and sputum of patients with chronic bronchitis $(9,10)$, and in one study the level of antibody in

Received March 3, 1994; accepted August 11, 1994

Correspondence: Professor A. Ferrante, Department of Immunology, Women's and Children's Hospital, South Australia, 5006, Australia.

This study was supported the Children's Research Foundation of South Australia and The National Health and Medical Research Council of Australia. these fluids correlated directly with the incidence of infection and mortality observed in these patients (10). This is despite the fact that bactericidal antibody to nontypable $H$. influenzae has been demonstrated and has been shown to be protective in nontypable $H$. influenzae-related otitis media (11-13). Patients with chronic bronchitis can support high colonization rates of nontypable $H$. influenzae in the presence of significant levels of bactericidal and opsonic activity in the serum (14). It has been suggested that the IgA anti-Haemophilus antibody in bronchopulmonary secretions blocks the bactericidal and opsonizing effects of antibody to the bacteria (15).

Using a rat model and immunization by intra-Peyer's patch injection with nontypable $H$. influenzae, it was shown that immunity could be transferred to naive recipients by $\mathrm{T}$ lymphocytes, but a primary protective role for antibody could not be established. Protection by T lymphocytes was manifested by increased clearance of bacteria from the lungs (16-18). No clear correlation was found between local or systemic antibody and bacterial clearance, and it was concluded that bacterial clearance is accelerated by factors that induce alterations in phagocytes (17). Immunized nude rats were less capable of 
accelerated clearance of nontypable $H$. influenzae compared with normal rats (16). These findings suggest that mechanisms for clearance of $H$. influenzae from the respiratory tract other than local or systemic antibody need to be investigated.

Recent evidence supports the concept that $\mathrm{T}$ lymphocytes are involved in recruiting and activating neutrophils at sites of infection (19). Czuprynski et al. (20) showed that immunologically specific $\mathrm{T}$ lymphocytes, in an antigen- and dosedependent manner, recruited neutrophils to a specific site. The recruited neutrophils, specific for Listeria monocytogenes, expressed high levels of bactericidal activity. Appelberg and Silva (21) demonstrated that $\mathrm{T}$ cells were important for inducing a persisting neutrophilia during intraperitoneal infection with Mycobacterium avium. Injection of antigen- pulsed spleen cells from $M$. avium-infected mice into the peritoneal cavity of normal mice caused a neutrophil accumulation at this site. Studies with a pathogenic free-living amoeba, Naegleria fowleri, demonstrated that neutrophils play an important role in immunity to Naegleria (22). Mice immune to this amoeba after immunization with killed antigen generated neutrophils that showed enhanced responses to the tripeptide f-Met-Leu-Phe (23) when challenged a second time with the antigen. Other studies have suggested that cell-mediated immune responses may be crucial for the activation of neutrophil-mediated killing of Nocardia asteroides in mice (24).

We have previously found that human $\mathrm{T}$ lymphocytes when activated by phytohemagglutinin-phorbol myristate acetate in culture were able to activate the neutrophil oxygen-dependent respiratory burst (25). In these studies, it was demonstrated that it was necessary for $\mathrm{T}$ lymphocytes to directly bind the neutrophils to induce these effects and that $\mathrm{T}$ cells actually primed the neutrophils for an increased response to f-Met-Leu-Phe and phorbol myristate acetate (25). Some evidence also has been presented suggesting that macrophages regulate the accumulation of neutrophils during inflammation (26).

Cytokines produced exclusively or preferentially by stimulated $\mathrm{T}$ lymphocytes have been shown to activate a range of neutrophil functions (27). These include LT (28-31), interferon- $\gamma$ (also a major product of natural killer cells) (29-34), and IL-2 $(35,36)$.

Other cytokines of interest that may have an effect on neutrophil activation are produced primarily by macrophages but can also be released by stimulated $\mathrm{T}$ cells. These include TNF $(30,33,37-40,41)$, IL-1 $(27,29)$, granulocyte-colonystimulating factor $(34,42)$, and IL-8 (43).

All of these cytokines can, in various ways, regulate the inflammatory response by acting on the neutrophil. They have the ability to increase neutrophil adhesion to the endothelium, to attract cells to infection foci via chemotaxis, to retain leukocytes at inflammatory sites by their migration inhibitory properties, and to activate the neutrophils with a subsequent increase in antimicrobial activity. In this study, the ability of the two related cytokines TNF and LT to alter the neutrophilmediated killing of nontypable $H$. influenzae has been investigated. The results show that both cytokines are effective in priming neutrophils to increase their bactericidal activity for nontypable $H$. influenzae.

\section{METHODS}

Bacteria. A nontypable $H$. influenzae was used in all experiments. The bacteria were grown on chocolate agar plates at $37^{\circ} \mathrm{C}$ for $24 \mathrm{~h}$, harvested, and suspended in HBSS. The bacterial concentration was quantitated immediately before use in a hemacytometer chamber. At the same time, an inoculum was made and spread on chocolate agar for verification of numbers of viable bacteria by colony formation.

Neutrophils. Neutrophils were prepared from the blood of healthy volunteers by the rapid-single-step method (44). The blood was mixed with heparin and layered onto a high density Ficoll-Hypaque medium $(1.114 \mathrm{~g} / \mathrm{L})$ and centrifuged at room temperature for $30 \mathrm{~min}$ at $200-600 \times \mathrm{g}$. After centrifugation, the mononuclear leukocytes appeared in a band at the interface, the neutrophils formed a band $1 \mathrm{~cm}$ below, and the red cells centrifuged to the bottom of the tube. The neutrophils in the second band were harvested and washed three times in HBSS. The neutrophils were of $>96 \%$ purity and $>99 \%$ viability by trypan blue dye exclusion.

The study was approved by the Ethics Committee of the Women's and Children's Hospital. Informed consent was obtained from the volunteers.

Bactericidal activity. Neutrophil bactericidal activity for nontypable $H$. influenzae was carried out essentially as described previously for Staphylococcus aureus (45). To $100 \mu \mathrm{L}$ of neutrophils $\left(5 \times 10^{6}\right)$ were added either $100 \mu \mathrm{L}(100 \mathrm{U})$ of TNF, $200 \mathrm{U}$ of LT, or $100 \mu \mathrm{L}$ of HBSS, and the mixtures were incubated at $37^{\circ} \mathrm{C}$ for $30 \mathrm{~min}$. After incubation, $1 \times 10^{6}$ nontypable $H$. influenzae were added and the volume made up to $500 \mu \mathrm{L}$ with HBSS. Because of the sensitivity of nontypable $H$. influenzae to serum complement-mediated bactericidal activity, human serum deficient in the sixth componcint of complement (C6D serum) was used in the assay as an opsonin at $4 \%$ (vol/vol) final concentration. C6D serum was prepared by depleting C6 from human serum by immunoadsorption (Sigma Chemical Co., St. Louis, MO). Controls were added in which the cytokine diluent (HBSS) was used in place of cytokines. In other experiments, the cytokine preincubation time and also the cytokine concentrations were varied. The tubes were gassed with $5 \% \mathrm{CO}_{2}$-air mixture and incubated at $37^{\circ} \mathrm{C}$ with end-toend mixing. Samples were taken at 0 and $30 \mathrm{~min}$, diluted in water, and plated on chocolate agar for determination of viable bacterial count.

Flow cytometric analysis of integrin expression. The expression of integrins on neutrophil surfaces was examined as previously described (45). Neutrophils $\left(5 \times 10^{5}\right)$ were incubated at $4^{\circ} \mathrm{C} / 30 \mathrm{~min}$ in the presence of saturating concentrations of MAb. After incubation, the cells were washed and stained at $4^{\circ} \mathrm{C} / 30 \mathrm{~min}$ with fluorescein-conjugated second antibody (goat anti-mouse IgG, Organon Teknika Corp., West Chester, PA) in the presence of $25 \%$ (vol/vol) autologous plasma. The cells were washed and fixed with $1 \%$ (wt/vol) paraformaldehyde. Fluorescence distribution was measured in a Becton Dickinson FACS analyzer (Mountain View, CA). Fluorescence values were corrected by subtraction of values for an isotype-matched negative control. Anti-CD11a (HB 202, IgG1) was TSI/22 (45), anti-CD11b (IOM-1, IgG) was from 
Immunotech, Marseilles, France, and anti-CD11c (kB90, IgG1) was from Dakopatts, Glostrup, Denmark.

Phagocytosis. Phagocytosis of nontypable $H$. influenzae was measured by a previously reported assay using FITC-labeled bacteria and flow cytometry analyses (46). The bacteria were labeled with FITC (Sigma) as previously described (46) and adjusted to $1 \times 10^{9} / \mathrm{mL}$ in HBSS. The bacteria $\left(1 \times 10^{8}\right)$ were then mixed with TNF-primed or diluent-treated neutrophils $\left(5 \times 10^{6}\right)$ in a total volume of $500 \mu \mathrm{L}$ that included $4 \%$ human C6D serum. After a 20 -min incubation at $37^{\circ} \mathrm{C}$ a $50-\mu \mathrm{L}$ sample was taken, added to $500 \mu \mathrm{L}$ of cold HBSS, and then treated with $0.065 \%$ trypan blue to quench fluorescence from adhered bacteria. The fluorescence due to internalized bacteria was measured on a FACSCAN (Lysis II program, Becton Dickinson, Sydney, Australia).

Cytokines. Human recombinant TNF was produced by Genentec Inc. (San Francisco, CA) and was kindly provided by Dr. G. R. Adolf, Ernst-Behringer Institute, Vienna, Austria. The recombinant TNF was produced in Escherichia coli, purified, and had a sp act of $6 \times 10^{7} \mathrm{U} / \mathrm{mg}$ as assayed by the supplier (cytotoxicity on actinomycin D-treated murine connective tissue cell line L929). Human recombinant LT was also from Genentec (provided by Dr. Adolf) and contained a sp act of $1.2 \times 10^{8} \mathrm{U} / \mathrm{mg}$. The preparations were $>99 \%$ pure and estimated to contain $<0.125$ endotoxin units $/ \mathrm{mL}$ of endotoxin.

Statistics. The data are presented as percentage of bacterial survival and analyzed using the $t$ test for paired data.

\section{RESULTS}

Treatment of human neutrophils with TNF significantly increased the ability of the cells to kill nontypable $H$. influen$z a e$ when serum opsonins were present (Fig. 1). TNF induced a 5 -fold decrease in the survival of the bacteria $(p<0.01)$. When serum recognition factors were inactivated by heating at $56^{\circ} \mathrm{C} / 30 \mathrm{~min}$, TNF failed to stimulate this activity (data not presented). The effects of TNF were evident at a TNF concentration as low as $1 \mathrm{U} / 5 \times 10^{6}$ cells $(p<0.001)$ (Fig. 2).

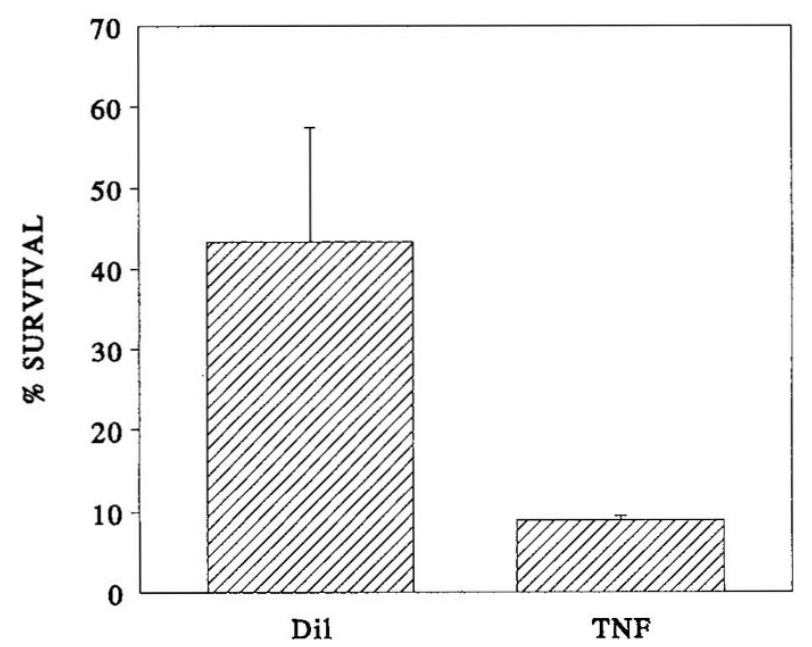

Figure 1. The effect of TNF on neutrophil bactericidal activity. Neutrophils were pretreated with either diluent (Dil) or $100 \mathrm{U}$ of TNF and then examined for bactericidal activity. The results are presented as means \pm SEM of our experiments each with cells from a different individual.

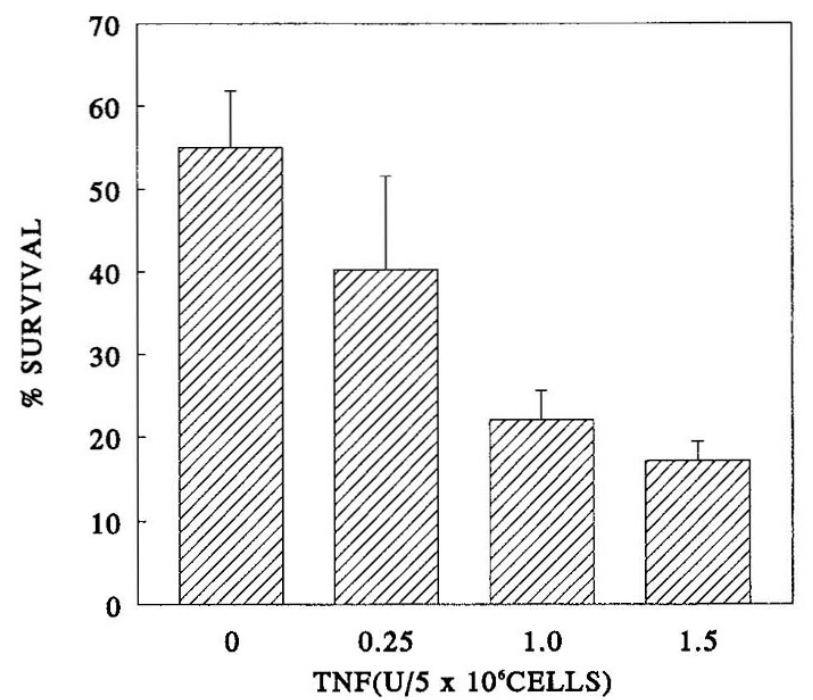

Figure 2. TNF concentration-related effects on the neutrophil bactericidal activity. Neutrophils were pretreated with the indicated concentrations of TNF and then tested for bactericidal activity. The results are the mean \pm SEM of three experiments each with cells from different individuals.

The related cytokine LT was also effective in enhancing neutrophil bactericidal activity. Neutrophils pretreated with LT showed significantly enhanced bactericidal activity (Fig. 3) $(p<0.01)$. Bacterial survival was decreased approximately 4-fold by treatment with LT. Studies on the concentrationrelated effects showed that $50 \mathrm{U}$ of LT were required to induce significant enhancement $(p<0.05)$ of bactericidal activity (Fig. 4).

Preincubation times of 30 to $60 \mathrm{~min}$ with TNF were most effective in enhancing neutrophil bactericidal activity (Fig 5). The degree of enhancement was gradually reduced as the preincubation time was reduced to less than $30 \mathrm{~min}$, although the simultaneous addition ( 0 time) of TNF and bacteria still resulted in a significant $(p<0.05)$ enhancement of the neutrophil bacterial killing.

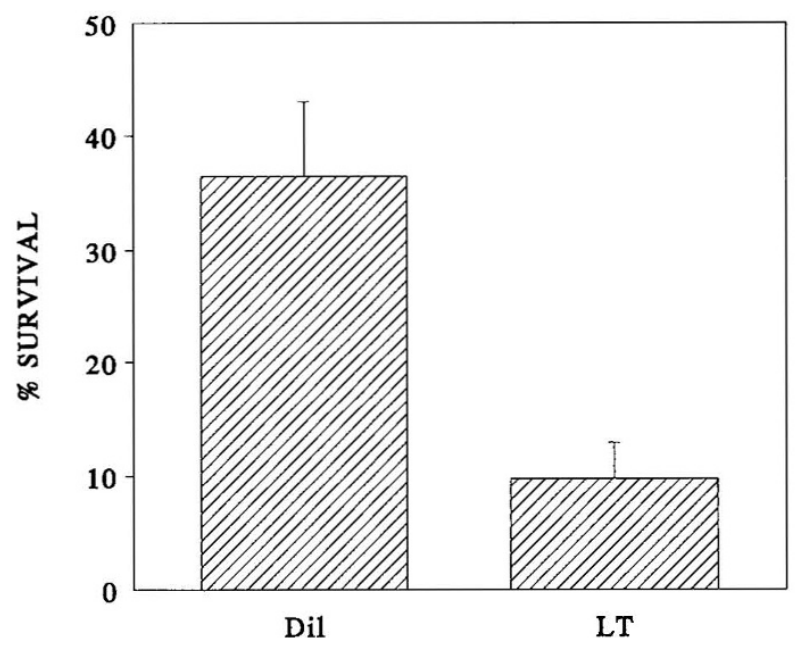

Figure 3. The effect of LT on neutrophil bactericidal activity. Neutrophils were treated with either $250 \mathrm{U}$ of LT or diluent $(\mathrm{Dil})$ and then tested for bactericidal activity. The results are presented as the mean \pm SEM of four experiments each conducted with cells from different individuals. 


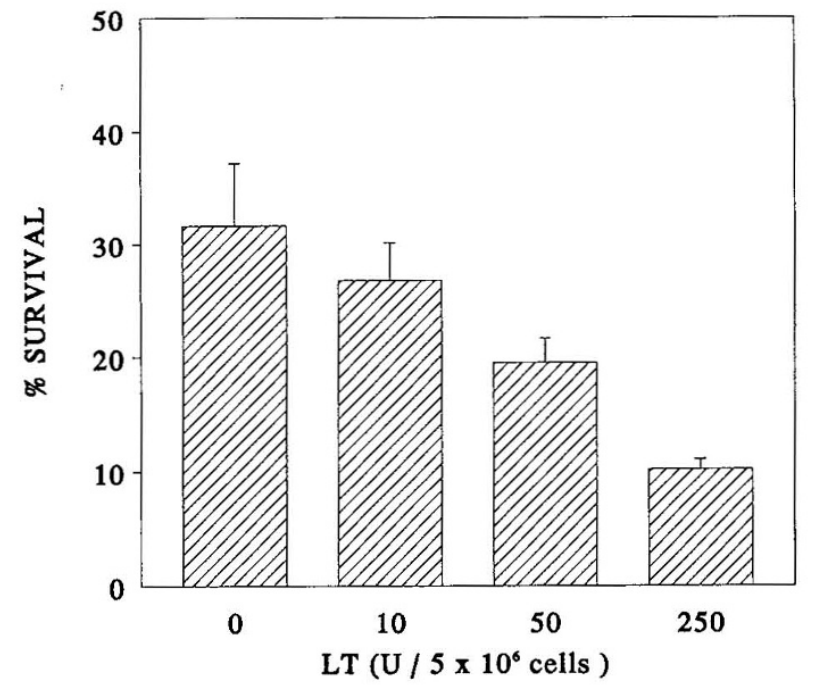

Figure 4. LT concentration-related effects on the neutrophil bactericidal activity. Neutrophils were pretreated with varying concentrations of LT and then tested for bactericidal activity. The results are mean \pm SEM of three determinations each with cells from the same individual.

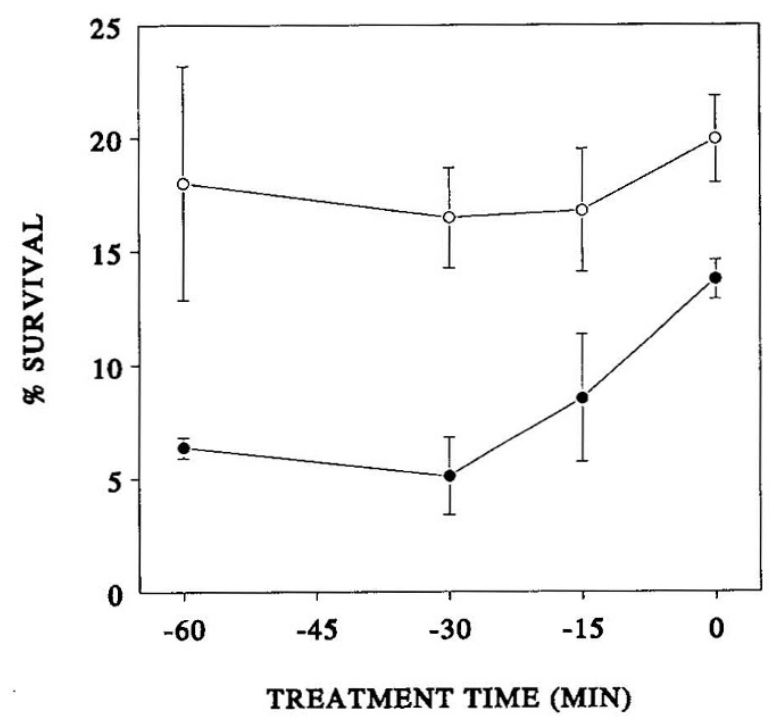

Figure 5. The effect of different TNF pretreatment times on neutrophil activation. Neutrophils were pretreated for $60,30,15$, and 0 min with either TNF $(\bullet)$ or diluent $(\bigcirc)$. The results are presented as mean \pm SEM of three experiments.

Additional studies showed that, under these conditions, TNF enhanced the surface expression of the neutrophil integrin receptors CR3 $(p<0.001)$ and CR4 $(p<0.01)$ (Fig. 6). However, TNF was unable to cause a significant change in the expression of the other integrin receptor, leukocyte functional antigen-1 (CD18/CD11a) (data not presented). Associated with this change in CR3 and CR4 expression, the TNF-primed neutrophils showed significantly enhanced $(p<0.05)$ phagocytosis of nontypable $H$. influenzae (Fig. 6).

\section{DISCUSSION}

The results demonstrate that preexposure of human neutrophils to TNF or LT significantly increases their ability to kill nontypable $H$. influenzae. The concentrations of cytokines required to achieve enhancement of neutrophil bactericidal

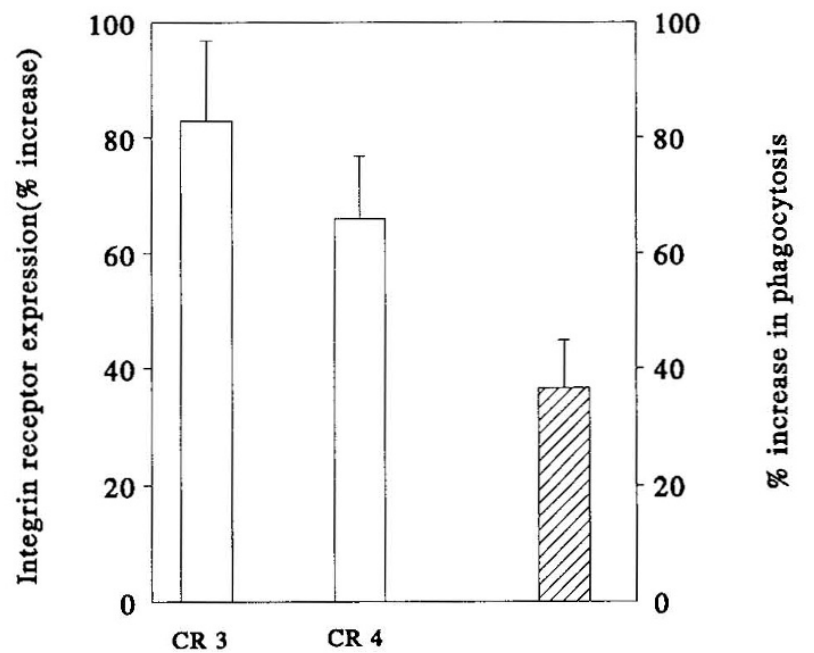

Figure 6. TNF-induced changes in CR3 and CR4 expression and in phagocytosis of $H$. influenzae. Expression of CR3 and CR4 was evaluated by flow cytometry using antibodies to $\mathrm{CD} 11 \mathrm{~b}$ and $\mathrm{CD} 11 \mathrm{c}(\alpha$-chain), respectively. The results are presented as the percentage increase in CR3/CR4 expression ( $\square$ ) and as the percentage increase in bacterial phagocytosis (Z) due to TNFneutrophil priming. The data are presented as mean \pm SEM of four experiments.

activity were within the physiologic concentrations achieved in vivo (46). Inasmuch as both TNF and LT were effective in this system, the results raise the possibility that macrophages, the major producers of TNF, and $\mathrm{T}$ lymphocytes, responsible for producing LT, may play an important role in immunity to nontypable $H$. influenzae. Our results may explain previous findings that showed that activated $\mathrm{T}$ lymphocytes and neutrophils were important for increasing the clearance of $H$. influenzae in rat lungs (16). From our studies, we suggest that these $\mathrm{T}$ lymphocytes enhance the neutrophil bactericidal activity against $H$. influenzae both by the release of LT and the activation of macrophages for release of TNF.

The effects of TNF and LT were seen in the presence of heat-labile serum factors. These were required for neutrophil killing of $H$. influenzae. When these factors were absent, neither TNF- nor LT-treated neutrophils showed any bactericidal activity. This is similar to our previous findings with $S$. aureus (45). Interaction of TNF and LT with neutrophils leads to increased expression of CR3 $(45,48)$, which allows the interaction of neutrophils with the C3bi opsonized bacteria. We have confirmed that TNF increases the expression of both CR3 and CR4 and now demonstrate that this enhancement of expression of CR3 and CR4 leads to enhanced phagocytosis of complement-coated $H$. influenzae. The increase in the number of bacteria phagocytosed and the well-established associated increase in the ability of the TNF/LT-primed neutrophils to show increased release of oxygen-derived reactive species and release of lysosomal enzymes (27) are most likely responsible for the enhanced microbial killing seen.

The role of antibody in immunity and protection from nontypable $H$. influenzae infection remains unknown (16-18), and it appears that $\mathrm{T}$ lymphocytes and production of neutrophil-activating cytokines are important in immunity against this organism (16-18). T lymphocytes are important in recruiting macrophages and neutrophils in the lungs and, as demon- 
strated by our studies, they activate neutrophils by releasing lymphokines, leading to increased neutrophil killing of nontypable $H$. influenzae and possibly clearance of the bacteria from the lungs. Our data suggest that identification of $H$. influenzae antigens that stimulate $\mathrm{T}$ cells to produce cytokines such as LT could prove to be useful in the search for appropriate vaccine antigens.

Acknowledgment. The authors thank Andrew Lawrence, Department of Microbiology, for the gift of nontypable $H$. influenzae and advice throughout these studies and Dr. Inge Kuwanko for assistance with the phagocytic assay.

\section{REFERENCES}

1. Kilian M, Heine-Jensen J, Bulow P 1972 Haemophilus in the respiratory tract of children. A bacteriological, serologic and clinical investigation. Acta Pathol Microbiol Immunol Scand [B] 80:571-578

2. Howard AJ, Dunkin K, Millar GW 1988 Nasopharyngeal carriage and antibiotic resistance of Haemophilus influenzae in healthy children. Epidemiol Infect 100:193203

3. Faden H, Stanievich J, Brodsky L, Bernstein J, Ogra PL 1990 Changes in nasopharyngeal flora during otitis media of childhood. Pediatr Infect Dis J 9:623-626

4. Long SS, Henretig FM, Teter MJ, McGowan KL 1983 Nasopharygeal flora and acute otitis media. Infect Immun 41:987-991

5. Bluestone CD 1988 Management of otitis media in infants and children: current role of old and new antimicrobial agents. Pediatr Infect Dis J 7:S129-S136

6. Carlen SA, Marchant CD, Shurin PA, Johnson CE, Murdell-Panek D, Barenkamp SJ 1987 Early recurrences of otitis media: reinfection or relapse. J Pediatr 110:20-25

7. Harrison CJ, Marks MI, Welch DF 1985 Microbiology of recently treated acute otitis media compared with previously untreated acute otitis media. Pediatr Infect Dis J 4:641-646

8. Liston TE, Foshee WS, McClaskey FK 1984 The bacteriology of recurrent otitis media and the effect of sulfisoxazole chemoprophylaxis. Pediatr Infect Dis J 3:20-24

9. Gump DW, Christmas WA, Forsyth BR, Phillips CA, Stouch WH 1973 Serum and secretory antibodies in patients with chronic bronchitis. Arch Intern Med 132:847852

10. Cripps AW, Clancy RL, Murree-Allen K, Engel MB, Pang G, Yeung S 1986 Quantitation of isotype-specific Haemophilus influenzae antibody in serum and saliva of normal subjects and chronic bronchitis. Asian Pac J Allergy Immunol 4:5-11

11. Shurin PA, Pelton SI, Tager IB, Kasper DL 1980 Bactericidal antibody and susceptibility to otitis media caused by non-typable strains of Haemophilus influenzae. $\mathrm{J}$ Pediatr 97:364-369

12. Karasic RB, Trumpp CE, Gnehm HE, Pelton SI 1985 Modification of otitis media in chinchillas rechallenged with non-typable Haemophilus influenzae and serological response to outer membrane antigens. J Infect Dis 151:273-279

13. Bakenkamp SJ 1986 Protection by serum antibodies in experimental non-typable Haemophilus influenzae otitis media. Infect Immun 52:572-577

14. Musher DM, Hague-Park M, Baughn RE, Wallace Jr RJ, Cowley B 1983 Opsonising and bactericidal effects of normal human serum on non-typable Haemophilus influenzae. Infect Immun 39:297-304

15. Musher DM, Goree A, Baughn RE, Birdsall HH 1984 Immunoglobulin A from bronchopulmonary secretions blocks bactericidal and opsonising effects of antibody to non-typable Haemophilus influenzae. Infect Immun 45:36-40

16. Cripps AW, Wallace FJ, Clancy RL, Husband AJ 1990 Role of intestinal T cells in pulmonary immunity to non-typable Haemophilus influenzae. In: McDonald $\mathrm{T}$, Challacombe S, et al. (eds) Recent Advances in Mucosal Immunology. Kluwer Academic Publishers, London, pp 172-175

17. Wallace FJ, Clancy RL, Cripps AW 1989 An animal model demonstration of enhanced clearance of non-typable Haemophilus influenzae from the respiratory tract after antigen stimulation of gut-associated lymphoid tissue. Am Rev Respir Dis 140:311-316

18. Wallace FJ, Cripps AW, Clancy RL, Husband AJ, Witt CS 1991 A role for intestinal $T$ lymphocytes in bronchus mucosal immunity. Immunology $74: 68-73$

19. Campbell PA 1990 The neutrophil, a professional killer of bacteria, may be controlled by T cells. Clin Exp Immunol 79:141-143

20. Czuprynski CJ, Henson PM, Campbell PA 1985 Enhanced accumulation of inflammatory neutrophils and macrophages mediated by transfer of $\mathrm{T}$ cells from mice immunized with Listeria monocytogenes. J Immunol 134:3449-3454

21. Appleberg R, Silva MT $1989 \mathrm{~T}$ cell-dependent chronic neutrophilia during mycobacterial infections. Clin Exp Immunol 78:478-483

22. Ferrante A 1991 Free living amoebae: pathogenicity and immunity. Parasite Immunol 13:S31-S47
23. Ferrante A, Hill NL, Goh DHB, Kumaratilake L 1989 Altered neutrophils in mice immune to experimental Naegleria amoebic meningoencephalitis. Immunol Lett 22:301-306

24. Felice GA, Niewoehner DE 1987 Contribution of neutrophils and cell-mediated immunity to control of Nocardia asteroids in murine lungs. J Infect Dis 156:113-121

25. Zhang J-H, Ferrante A, Arrigo A-P, Dayer J-M 1992 Neutrophil stimulation by activated T lymphocytes. J Immunol 148:177-192

26. Issekutz AC, Megyeri P, Issekutz TB 1987 Role for macrophage products in endotoxin-induced polymorphonuclear leukocyte accumulation during inflammation. Lab Invest 56:49-59

27. Ferrante A 1992 Activation of neutrophils by interleukins- 1 and -2 and tumor necrosis factors. In: Coffey RG (ed) Granulocyte Responses to Cytokines, Basic and Clinical Research. Marcel Dekker, New York, pp 417-456

28. Ferrante A, Nandoskar M, Bates EJ, Goh DHB, Beard LJ 1988 Tumour necrosis factor-beta (lymphotoxin) inhibits locomotion and stimulates respiratory burst and degranulation of neutrophils. Immunology 63:507-512

29. Figari IS, Mori NA, Palladino Jr MA 1987 Regulation of neutrophil migration and superoxide production by recombinant tumor necrosis factors- $\alpha$ and $-\beta$ : comparison to recombinant interferon $\gamma$ and interleukin- $1 \alpha$. Blood 70:979-984

30. Shalaby MR, Aggarwal BB, Rinderknecht E, Svedersky LP, Finkle BS, Palladino Jr MA 1985 Activation of human polymorphonuclear neutrophil functions by interferon- $\gamma$ and tumour necrosis factors. J Immunol 135:2069-2073

31. Kumaratilake LM, Ferrante A, Rzepczyk CM 1991 The role of $\mathrm{T}$ lymphocytes in immunity to Plasmodium falciparum enhancement of neutrophil-mediated parasite killing by lymphotoxin and interferon gamma. Comparisons with tumor necrosis factor effects. J Immunol 146:762-767

32. Kowanko IC, Ferrante A 1987 Stimulation of neutrophil respiratory burst and lysosomal enzyme release by human interferon-gamma. Immunology 28:591-598

33. Bignold LP, Ferrante A, Haynes DR 1990 Studies of chemotactic, chemotactic movement-inhibiting and random movement-inhibiting effects of interleukin-1 alpha and beta, tumour necrosis factors alpha and beta and interferon gamma on human neutrophils in assays using 'sparse-pore' polycarbonate (nucleopore) membrane in the Boyden chamber. Int Arch Allergy Appl Immunol 91:1-7

34. Steinbeck MJ, Roth JA 1989 Neutrophil activation of recombinant cytokines. Rev Infect Dis 11:549-556

35. Kowanko IC, Ferrante A 1987 Interleukin 2 inhibit migration and stimulates respiratory burst and degranulation of human neutrophils in vitro. Immunol Lett 15:285301

36. Morrison CJ, Brummer E, Isenberg RA, Stevens DA 1987 Activation of murine polymorphonuclear neutrophils for fungicidal activity by recombinant gamma interferon. J Leukocyte Biol 41:434-440

37. Klebanoff SJ, Vadas MA, Harlan JM, Sparks LH, Gamble JR, Agosti JM, Waltersdorph AM 1986 Stimulation of neutrophils by tumour necrosis factor. J Immunol 136:4220-4225

38. Gamble JR, Harlan JM, Klebanoff SJ, Vadas MA 1985 Stimulation of the adherence of neutrophils to umbilical vein endothelium by human recombinant tumour necrosis factor. Proc Natl Acad Sci USA 82:8667-8671

39. Perussia B, Kolsayashi M, Rossi ME, Anegon I, Trichieri G 1987 Immune interferon enhances functional properties of human granulocytes: role of Fc receptors and effect of lymphotoxin, tumor necrosis factor, and granulocyte-macrophage colony stimulating factor. J Immunol 138:765-774

40. Ji Ming W, Bersani L, Mantovani A 1987 Tumor necrosis factor is chemotactic for monocytes and polymorphonuclear leukocytes. J Immunol 138:1469-1474

41. Nathan CF 1987 Neutrophil activation on biological surfaces. Massive secretion of hydrogen peroxide in response to products of macrophages and lymphocytes. J Clin Invest 80:1550-1560

42. Kowanko IC, Ferrante A 1991 Granulocyte-macrophage colony stimulating factor augments neutrophil-mediated cartilage degradation and adherence. Arthritis Rheum 34:1452-1460

43. Baggiolini M, Walz A, Kunkel SL 1989 Neutrophil peptide-1/interleukin 8, a novel cytokine that activates neutrophils. J Clin Invest 84:1045 1051

44. Ferrante A, Thong YH 1982 Separation of mononuclear leukocytes from human blood by the one-step Hypaque-Ficoll method is dependent on blood column height $\mathrm{J}$ Immunol Methods 48:81-85

45. Ferrante A, Martin AJ, Bates EJ, Goh DHB, Harvey DP, Parsons D, Rathjen D, Russ G, Dayer J-M 1993 Killing of Staphylococcus aureus by tumor necrosis factor- $\alpha$ activitated neutrophils: the role of serum opsonins, integrin receptors, respiratory burst and degranulation. J Immunol 151:4821-4828

46. Bredius RGM, deVries CEE, Troelstra A, van Alphen L, Weening RS, van de Winkel JGJ, Out TA 1993 Phagocytosis of Staphylococcus aureus and Haemophilus influenzae type $\mathrm{B}$ opsonized with polyclonal human $\mathrm{IgG1}$ and $\mathrm{IgG} 2$ antibodies. Functional $\mathrm{hFc} \gamma \mathrm{R} 11 \mathrm{a}$ polymorphism to IgG2. J Immunol 151:1463-1472

47. Clark IA, Gray KM, Rockett EJ, Cowden WB, Rockett KA, Ferrante A, Aggarwal BB 1992 Increased lymphotoxin in human malaria, its ability to increase plasma interleukin- 6 and cause hypoglycemia, and possible role in malaria pathology. Trans R Soc Trop Med Hyg 86:602-607

48. Gamble JR, Harlan JM, Klebanoff SJ, Vadas MA 1985 Stimulation of the adherence of neutrophils to umbilical vein endothelium by human recombinant tumor necrosis factor. Proc Natl Acad Sci USA 82:8667-8671 